\title{
[7]
}

\section{"The One Who Writes Us": Political Allegory and the Experience of Occupation among the Mzeina Bedouin}

\author{
Smadar Lavie
}

\begin{abstract}
Allegory arises in periods of loss, periods in which a once powerful theological, political, or familial authority is threatened with effacement. Allegory arises then from the painful absence of that which it claims to recover, and,... as the paradox of an order built upon its own undoing cannot be restricted to this one discursive mode, indeed, ... the longing for an origin whose loss is the necessary condition of that longing is the character not only of all discourse but of human existence itself.
\end{abstract}

-Stephen Greenblatt,

"Allegory and Representation"

On 24 September 1978, Anwar Sadat, Menachem Begin, and Jimmy Carter signed an almost final draft of a peace accord at the Camp David retreat that was to give the accord its name. At that moment, thousands

This essay is based on thirty months of fieldwork carried out between 1975 and 1979 in the South Sinai Peninsula, and three additional short trips made in August 1981, December 1985, and April 1987, sponsored by the Ford Foundation and by the Lowie 
of miles away, in the very Sinai desert on which all the diplomatic hullabaloo had been focused, I labored in 'Ein al-Akhadar, ${ }^{1}$ a Mzeina oasis. An Israeli anthropologist of half-Yemenite, half-Lithuanian heritage, I listened to the Arabic version of the news as it wafted in a scratchy voice across the hot, lugubrious atmosphere of the mag'ad rejjal (men's club). ${ }^{2}$ Two days later I was to be the victim of the local fool, who sent me to a deserted well in the middle of nowhere. There I spent a memorable night alone on an empty stomach. The previous day's tragedy was compensated for the following day by a remarkable stroke of good luck: here, in the middle of nowhere, I met a Mzeini woman. In a display of typical Bedouin hospitality and generosity, she shared with me what little food she had and took me to her encampment.

A month later, my pride still smarting, I related my humiliation to several Mzeinis. I was surprised at myself in that, despite my embarrassment I mustered-without really trying to-the calm, distanced style that typifies Bedouin storytelling. Had my audience been professional anthropologists, I no doubt would have delivered a disquisition on "The Impact of Global Politics on the Tribal Structure of the Mzeina." But as my story represents not so much distancing, objective observations by a detached scholar, but deeply felt experiences shared with the Mzeinis, it is best told as an allegory. After all, at those points where my identity and that of the Mzeinis meet and converge, the global politics observed and analyzed by scientists become the local poetics experienced and lived by the participants.

The mundane dialogues of the Mzeinis reflected their inconsistent and insecure living conditions. These were consequences of the occupation of the Sinai, a political football tossed back and forth between Egypt and Israel. ${ }^{3}$ When the Mzeinis pondered how they ought to relate to the Israeli or Egyptian soldiers, the military governors, the civil administrators, the assorted settlers, and the international tour-

\footnotetext{
Fund of the Anthropology Department, U.C. Berkeley. The issues presented are discussed in greater detail in my book, The Poetics of Military Occupation: Mzeina Allegories of Bedouin Identity under Israeli and Egyptian Rule (Berkeley: University of California Press, 1990). I am also grateful to the MaBelle McLeod Lewis Fund and the Hebrew Free Loan Association for their support during the writing stages. And last but not least, I wish to express my heartfelt gratitude to the 5000 or so Mzeinis, to whose tradition of hospitality I am deeply obliged.
} 
ists, they were faced by the dilemma of adapting traditional hospitality to quite untraditional "visitors."

Karwat ad-deif, or the code of hospitality, was a pillar of Bedouin tradition. Mzeinis viewed it as a sacred commitment on the part of each tribal member to the honor of his or her community and tribe, and to the honor of the Tawara, the tribal alliance to which the Mzeina belonged. Hospitality also embraced spheres beyond the tribe. Hospitality toward any member of the community of Muslim believers (al-umma al-Islamiyya), or to anyone in the whole world (ahl al-dunya) visiting the South Sinai, was to bring honor to the Mzeini displaying it. The duty of hospitality involved both the tribal structure and its many organizational modes. Any stranger who came to the Sinai was traditionally considered a guest and was expected to introduce himor herself according to a rigid etiquette reflecting tribal and regional affiliation. If a guest was not known to the host from previous meetings, the guest was to introduce him- or herself by name and give a threeto five-generation genealogy of his or her khamsa (feud group), clan and phratry affiliations, and the tribe of which he or she was a member. Since among the Mzeina descent and territoriality did not exactly correspond, the guest also mentioned the name of the regional alliance to which he or she belonged. Then, before turning to talk of other matters, the host and guest gossiped about the overlapping areas of their kinship and friendship networks.

Many of the Bedouin dialogues on the nature of hospitality degenerated into bitter arguments where the participants' value of honor, derived from being Bedouin hosts, was confronted by the indeterminacy characterizing their life as voiceless pawns of their uninvited guests. Many of these arguments ended abruptly and inconclusively. But sometimes, the collision between the many voices of the present, and a monologic voice that recited the inheritance of a pre-colonial tribal past, fractured the taken-for-granted construction of everyday reality (Berger and Luckman 1967: 19-28). During these fragile interstitial moments, existential paradoxes emanating from the world geopolitical situation surfaced in Mzeinis' everyday discourse.

At such moments, any person of theatrical and rhetorical talent might speak up spontaneously, playfully allegorizing an exceptionally painful or humorous yet mundane experience into a story told in the Mzeina traditional, monological storytelling style. In so doing, the teller transcended both personal and communal experiences and incorporated them into the tribal tradition. I refer to these tellers as 
playing out "allegorical types." These "types" are my anthropological constructs. But cultures also pay tribute to creative personae. I found that some of "my" personae constituted the central characters in traditional stories (hikayāt) and poems (gașid) recited by many Mzeinis.

Once, during a liminal moment (Turner 1967: 93-111) when the tradition of hospitality was called into question, I found myself acting as an "allegorical type." Allegorizing my memorable night experience, I was able to bridge the gap between the Mzeina's tradition of hospitality and the inconsistencies of their current lives. As guest and yet as the most marginal tribesperson, as a Jew of both European and Arab descent, someone conjoining Self and Other in herself, ${ }^{4}$ I spontaneously staged an allegory enabling my audience and myself to reconstruct the tradition of hospitality in both reality and structure. I was thus able to momentarily resolve the ambiguities associated with Mzeina hospitality and the paradoxes faced by Mzeina (and myself) in relating to Western culture and politics.

\section{II}

I will begin decoding the contradiction and mystery of being sent to the wilderness by a Fool, and of being saved the next day by a woman, both members of the same tribe, referring to portions of my field diary. ${ }^{5}$ All references to "days before" refer to the number of days before my encounter with the oasis Fool.

$\boldsymbol{i}$

26 September 1978, Bir al-Sarādga

Dear Diary,

I thought my war scars from the Sinai healed since I treated them with anthropological hopes for mutual understanding. To hell with it! Here I sit, in the middle of nowhere, and instead of writing my regular evening fieldnotes, I stupidly write "Dear Diary."

After almost three years of fieldwork, years when I imagined myself crossing the emotional wilderness of mutual distrust, years when I assumed that I, an Israeli anthropologist, had exposed the essence of my Self to that Bedouin Other, and years in which that Other, in exchange, seemed to absorb me into itself. After all, we are but trivial 
beings who disintegrate into small particles in the shadow of the ArabIsraeli conflict.

The dark sky awaits the late moonrise. Smadar, how did you ever get into this?

Five days before.

21 September 1978, Farānje

The Pilgrimage to Farānje [Mzeina's ancestral tomb] _... . The ambitious and vague hopes of Camp David have shrunken here to penetrating questions: about the temporary borderlines that will separate families during the gradual return of the Sinai from Israel to Egypt between 1979 and 1982; about how to obtain licenses to visit relatives on both sides of these borders; about the shrinking possibilities of migrant work with the Egyptians and Israelis; about speculations that further development projects will be imposed on the locals... .

22 September 1978, Farānje, still

Four days before.

Ashes of the pilgrimage. Bedouin cynicism about the real importance of the Sinai in future peace treaties. And their nice rhyme. "The Sinai mountains-good for naught. Can't be used, can't be bought." Jebäl Sina-la lehum 'aida wamafish minhum faida.

... Noon prayer-Afterward I join the galid (or the Symbolic Battle Coordinator of the tribe), his one-eyed brother, and the entourage made up of three ancient customary judges. We bump along for about a half an hour-five nobles resplendent in formal robes and one anthropologist in baggy jeans and T-shirt, six people in a dilapidated pickup going to 'Ein el-Akhadiar.... ${ }^{6}$

... 'Ein al-Akhadar-The green spring. The whistling wind in the wide wadi. Rounded black hills of metamorphic rock flowing forth from the windswept plateaus of the peninsula's watersheds. A few small fruit orchards and date trees embrace the wadi wall. Often the fruit does not ripen because of the cold. A well, buckets, a sweep. The Mzeina call this oasis, which sits on the fringes of their territorial center, "our heart."

Two days before.

24 September 1978, 'Ein al-Akhaḍar

... It is said, rather cynically, that the customary residence of the Symbolic Battle Coordinator is here, in the heart of Mzeina. But alas, 
nothing stirs in this heart but two young goatherds, some twenty goats, and a donkey burdened with six empty water jerrycans. Every other morning the girls emerge from the yellow dunes, wash their long hair near the well, fill up the jerrycans, and disappear again into the dunes in the direction of their summer encampment.

Like Mzeina elders everywhere, the Coordinator and his entourage spend most of their days and nights sitting or reclining in the magad. But the mag'ad in 'Ein al-Akhaḍar is the only sign of community life in this forsaken tribal heart.

... A transistor radio barks out news in Modern Standard Arabic (and thus it is only partially understood by these nomads because they speak a dialect). Someone painstakingly scans the dial in an almost desperate search for the elusive stations. Our ears strain to discern meanings amidst the scratches, while our eyes focus on a square drawn in the sand. Finger-made crosshatchings transform the sand into a checker board. The Judge and the Coordinator while away their days in a sequence of slow and calculated shiza games [a crossbreed between "checkers" and "go"]. One player moves small pieces of dry, pale camel manure; the other player uses small pebbles of red granite. Some of the entourage bless the players with their unsolicited advice, while others advise the advisors, until one can no longer tell players from advisors, or advisors from advisors of advisors.

"Shgētef, could you pour more tea?" the Coordinator nonchalantly requests the local Fool. ${ }^{7}$ The Fool enters the magad and for the umpteenth time pours us yet more cups of hot sweet tea.

.. "So what did the news say?" the Coordinator asks the man with his ear glued to the transistor, but doesn't wait for an answer. "I'll tell you," he says with a half-bemused, half-serious expression, "No one will solve the problems between Russia and America. Only the Chinese will ever figure a way out. And when the day comes that they conquer the Sinai, that will be the end of that."

It's a good pun-the Arabic for "Sinai" is Sinna, for "Chinese" is Sini-and we laugh heartily. But the Fool, perhaps betraying his deep wisdom, stares at us with eyes wide open.

The Coordinator continues, "The Greeks were here and left behind the Monastery [Santa Katarina], the Turks were here and left behind the Castle [in Nuwēb'at Țarabīn], and the British drew up maps, and the Egyptians brought the Russian army (and a few oil wells), and the Israelis brought the Americans who made the mountains into movies, and tourists from France and Japan, and scuba divers from Sweden 
and Australia, and - trust Allah to save you from the devil—we Mzeina are nothing but pawns in the hands of them all. We are like the pebbles and the droppings of the shiza."

Everyone but the Fool again roars with laughter. The Coordinator points to me with his long index finger, saying in a commanding voice, "Write it all down, The One Who Writes Us!" (di illi tuktubna-one of my two Mzeini nicknames).

26 September 1978, 'Ein al-Akhaḍar, still ... Noon-Enough, I am shiza-ed out. Between shiza moves the men exhaust most of the possible scenarios for the near and distant future of the Middle East. The Egyptian-Israeli peace treaty may loom large on the global horizon, but locally it has been torn to shreds.

... I recall a nearby well, Bir al-Sarādga, six kilometers down the wadi. Several families encamped there during winter. I wonder how Sadat's peace initiative echoes in the walls of this well. The negotiated temporary border will pass right through it.

I ask Shgettef (the Fool) if there are any camels grazing in the surrounding hills and if it might be possible to rent one, to load it with cameras, cassette recorder, a huge and clumsy backpack (just thirty kilograms altogether) and travel to Bir al-Sarādga. Shgētef raises one eyebrow, a Bedouin gesture indicating a dubious "why not?" I join him in the search for fresh camel footprints. We search in vain. He stares at me, pretending to be amazed, and says, "Ya Smadar, owner of big hips [omn al-ja' $a b$-my other nickname], a tough and skillful Israeli like you, who lives with us in this desert, can't even load yourself up and go down the wadi as far as Bir al-Sarādga? The Bedouin encamp right there, winter and summer."

26 September 1978, Bir al-Sarādga

Here, again, at tonight's page-

... And I carried myself and my heavy load down the wadi. When I saw the well from afar-I felt relieved. The place hadn't changed since winter. For a moment I thought I heard a dog bark in the distance, suggesting the existence of an encampment. But alas, arriving at the well I found only the leftovers from the previous winter encampment. I dropped my stuff near the well and started walking quickly, almost hysterically, in one direction after the other, hoping to find someone, anyone, before nightfall. Within the radius of a kilometer not a living thing was to be found. Around the well were 
many fresh footprints of women and children, but still I dared not hope.

I am afraid. I had trusted Shgētef, a channel for the region's gossip. But while the tribe's resplendent leadership expressed their anger at the Camp David Accord verbally, the fool, as a Fool, acted out his anger by dispatching the most available Israeli to the middle of nowhere. Now I know what the Mzeina mean when they say, "The fool's mind is sharp as a sword."

As the day recedes into dusk, I gather some dry twigs and light a small fire. I have no food, but at least I have enough cigarettes and matches to get me through the night. OK, I will try to fall asleep. Tonight, even the habitual sadness of sunset does not move me.

Maybe I deserve it?

27 September 1978, Bir al-Sarādga

... A new day-During the night I jolt awake several times, shivering with fear, unable to decide whether to be angry at myself or at Shgettef. Finally I wake up at 7 a.m. and decide that, if no one arrives at the well by eight, I will leave my stuff, fill my three canteens, and continue down the wadi for twenty-five kilometers to the settlement where Wadi al-Akhadar meets Wadi Firān. It is inhabited the year around, and this $I$ know without having to count on any clever fool.

I am starved, and the sun beats down on everything. My back hurts from yesterday, but I've got to go on. After a hurried walk down the wadi I suddenly see a Bedouin woman, two toddlers, and a donkey loaded with empty jerrycans. Are these the owners of the footprints I found yesterday near the well? My eyes fill with tears of relief. The woman notices me and veils herself. From afar we exchange the customary greeting sentences said between a guest and a host. Hoping that she does not notice, I wipe my tears away with my Mickey Mouse T-shirt. Bedouin are not supposed to cry.

$i i$

After a month I returned to Dahab, a community in the process of sedentarization on the shore of the 'Aqaba Gulf. There lived the family that offered me tribal protection as an adopted daughter $\left(\tan \bar{i} b a^{8}\right)$, after I decided to adopt Dahab as a base camp for anthropological migration. But rumors of the misdeeds of Shgettef-the-Fool, and of my 
rescue by the woman with her two toddlers, arrived in Dahab even before I did.

28 October 1978, Dahab

Wintry Dahab-The north wind has already swept away the scents of dinner and the last whispers of the 'asha (after-dinner) prayer. The tales of the fearful Abu-Zāyed, accompanied by the sad sound of a rabāba (one-string fiddle), ooze out of the transistor radios whose antennas are trained towards Egypt, and pour into the night.

Flattened cartons and wooden boxes, supported by dry palm branches, are the materials out of which Ghānma and Mūsa's hut has been fashioned. In the inner yard Ghānma, Abu-Mūsa (Mūsa's old father), who makes his living from fishing, and Omm-Mūsa (Mūsa's mother) sit in a circle around the transistor radio. The scene is faintly illuminated by glowing embers. A tea kettle bubbles above red hot coals. Next to Ghānma sit Mabsūța and Rāshda—two neighbors whose husbands are now employed as unskilled, underpaid, but tenured workers at the Israeli army camp at Sharm al-Sheikh. 'Id and Salìm, their elbows resting on their woolen body wraps, recline near AbuMūsa. 'Id is a neighbor temporarily hired several times by the local Israeli ranger to clean up the heaps of trash left by tourists. Salim is married to Omm-Mūsa's brother's daughter, and lives in the western peninsula, to be returned to Egypt next summer. He is about to go job hunting in the Israeli town of Eilat. Smadar, an Israeli anthropologist, huddles in the corner, trying to write down every detail.

When the legendary feats of Abu-Zāyed are completed, Salīm nonchalantly turns the radio dial in search for the evening news. We gallop between Cairo, Monte Carlo, Damascus, Jerusalem, Amman, the Voice of America, London, straining to catch elusive radio stations amidst serious Standard Arabic voices relating bits of news. ${ }^{9}$

Mabsüta (puzzled): The people in the radios-they always say the same things. But each station and every state says it in its own way. It's something I don't understand. Never.

Omm-Mūsa (with an air of indifference): Every one and his rabāba. 'Id (sarcastically): Ah-ha-what's the distance between Abu-Zāyed's rabāba and the rabāba of the news-(laughs to himself and lowers the transistor's volume.)

Ghänma (briskly, switching the radio off): Enough! I'm fed up with the news. All or one, they're the same! Tea? 
Pause. Ghänma once again fills the empty tea cups handed to her. Some, attempting to chill the boiling tea, whistle air through their lips.

Abu-Mūsa: Ya Salīm, soon we will need a passport and some licenses in order to visit you and your family — and your family is our family. [Salìm is a member in Musa's lineage in addition to his marriage to Omm-Mūsa's brother's daughter.] What do you think (a mischievous look in his eyes), will the Egyptians photograph my bald head in color, or black and white?

He laughs and the rest join in.

Salim (with a raised voice): Folks, this is not the time for jokes! When the Egyptians find out that I drive a Russian jeep [left behind in 1967] you will probably need to apply for a license to visit the jail.

Mabsūta: Drop it. A lot of time has passed since then. They've forgotten all about it.

Salim (louder): I swear to God, they haven't forgotten. (Slowly, emphasizing each word): When they got Ras-Sadr back [in 1976, due to Kissinger's shuttle diplomacy] they fined everyone who drove Russian vehicles. Those who couldn't afford to pay went to jail. I heard it from those who came [from the Egyptian-controlled] RasSadr area for visits to relatives through the Red Cross.

Omm-müsa (awakening): Aii-wa! (yeah), this is the time for us to start thinking where to hide what we took from the Egyptians, and to start "collecting" things from the Jews. [The term "Jews" was often used to describe the generic anyone who was not Bedouin and who came to the Sinai during the Israeli occupation, including tourists from all over the world, and even Palestinians.]

'Id (to Salim): I heard that somebody from your encampment has "taken" a Mercedes taxi from Eilat with the help of friends, took it apart, hid it in the wadis, and the Israeli police couldn't find a thing.

Abu-Müsa (playing with the prayer beads between his fingers, mutters to himself): Haräm! (taboo!)

Salim (chuckling): They said that some got arrested in Eilat, but were freed. Lack of evidence, they said.

Abu-Mūsa (to himself): Thank God! (Thoughtful for a moment) Still, it's harām!

A silent pause. 
Mabsuta: My husband says he doesn't know what to do-to leave his work and start "collecting," or wait till the Israelis are about to leave and get his severance pay-he worked for them since 1972 .

Omm-Müsa: If they'll give him his severance pay in dollars, let him wait. If in Israeli pounds, he should "collect" other things since the Israeli money is nothing but worthless paper, buying us nothing from the Egyptians. But if you ask me, I think he should both "collect" and take his severance pay. This time, it doesn't look like these Israelis will return again for several years.

Abu-Müsa (stops playing with his prayer beads, firmly): Ya wife, the Bedouin don't work at and steal from the hand greeting them with peace, be it Egyptian, Israeli, or Greek. Our God is one, and all of us wish to live in honor and peace. Enough of this ugly talk! Israelis, Egyptians, and all the rest of them are now our guests in the Sinai, and our code of hospitality is well known and respected!

'Id: You mean, every 'id, țît, and 'afrìt ["holiday," "twitter," and "demon"] who arrives here must be received as if he were a Bedouin? I will go bankrupt if I have to host those strangers!

Ghānma (very angry): Ya Abu-Mūsa, guests don't give you ID cards and licenses and tell you where to go and where not to! Guests don't employ you or give you severance pay! Guests don't prescribe you medications or take your blood samples to Tel Aviv! Guests don't govern and punish you! What sort of guests are you talking about? We are all quiet for several hesitant moments.

Rāshda: And what about the huts in al-Billij? [Al-Billij was the fake Bedouin village built by Dahab entrepreneurs for the many tourists seeking a vacation in an "authentic" Bedouin atmosphere, while sunbathing in various degrees of nudity or diving in spectacular coral reefs.] We have four huts. Now we have there a couple from near Tel Aviv, a German couple, three girls from some moshāv [Israeli agricultural co-op], and a strange American guy with a long beard-yuukk! — who doesn't haggle with my son over the price, and doesn't lie naked on the beach. Always, when the tourists come, they buy clothes like ours. And my son, he prepares for them farashih [flat bread] and tea. Sometimes some suckers give him some of their food, because they think he's hungry. Afterwards (bemused, chuckling) they also pay for what he prepares for them. And this sort, they want to be like us. Sometimes, when I see them from 
afar, dressed in our men's robes, believe me, I am not sure who they are.

Omm-Müsa (angrily): We also have to "take" from them: sleeping bags, watches, dollars. Half of the day, when not dressed in our clothes, they go around naked and screw each other in front of all. ${ }^{10}$ Disgusting! (She spits on the ground.) These are no Bedouin!

'Id(shouts): So tell me, you, Omm-Mūsa! Tell me, you (pointing with his long index finger at each person sitting in the circle), and you, all of you! Who are the Bedouin and who are the guests?! Our kidsthey run around in Eilat and Sharm al-Sheikh with pants and shirts, and not only during worktime. (Lowering his voice) Do you remember the film that they shot about the life of-what's his nameBrian, in the Castle of Nuwēb'a? That Inglizi [Englishman] wanted forty Bedouin who would work with him [as extras]. When they came, they dressed up for work [i.e., with pants], and he was wearing a caftan and a headdress. He yelled at them: "You, Bedouins, should come to work as Bedouin, because you have to be Bedouin in the film." (Raising his voice) See how? Soon will be the day when men start showing up with pants to the mag'ad!

There is a short, though disquieting, silence.

Abu-Müsa (shaking his head, to himself): And we, where shall we go? These days, even the tradition of hospitality is not with us any more. We don't know who is Bedouin and who is a guest. We don't know whether our guests respect us nor how we should respect them. And Honor has left us, disappeared....

A long silence prevails. When honor is mentioned, silence always descends: honor is holy. The stormy wind, still beating the date trees, now brings us the sounds of a faraway cassette recorder.

The anthropologist finishes writing Abu-Mūsa's question and I tell her to try to immerse herself in the dim and distant sounds of the field night. Instead, she embarrassedly points to the fact that my fresh memories of that scary Bir al-Sarādga experience are now emerging from the silence.

When I finally arrived at Dahab after the Shgettef-the-Fool episode, Abu-Mūsa and several other elders insisted that I take Shgētef and his khamsa to the tribal customary court for having sent me off into the wilderness. Yet as an Israeli I felt I hardly had any right to stay with the Mzeina, let alone sue them.

But this evening Abu-Mūsa's penetrating question shakes me. I want 
to tell the people present that, despite the intrusions of the many foreign agencies into their daily life, ideas like tribal structure, social organization, and rituals of tradition remain alive and well. As a matter of fact, every day I fill my notebook with them.

"I swear to God, ya Abu-Mūsa," I burst out. "Among the Mzeina, a guest is still a guest, and hospitality is hospitality. If one has a khamsa or is offered protection $[\tan \bar{i} b]$ by such a group, if that person or the ones who have offered protection have only, really, only one karat of dates [every date tree contains twenty-four karats, which are twentyfour parts of shared ownership], then it becomes as clear as the morning's sun when one is a guest and when one is a host." In this way I repeat to Abu-Mūsa and "Id what they once told me about tribal membership and hospitality.

All eyes are focused on me. I feel the urge to continue, and tell the happy ending to my 'Ein al-Akhadar experience.

"You might have heard how Shgētef-the-Fool fooled me when I wanted to visit the people of Bir as-Sarādga," I ask rhetorically.

"A deed which should not be done among us," some murmur to themselves.

I take a long breath. As I start narrating, the anthropologist reminds me: Smadar, now narrate your personal experience in Bedouin storytelling style. Don't be emotional. It is not allowed!

"After I spent the night alone, I woke up the next morning and decided to go down to where Wadi al-Akhadar meets Wadi Firan. I knew that people were there. I walked for a bit down the wadi. Suddenly I saw a woman, two toddlers, and a donkey climbing towards the well. When the woman noticed me, she veiled herself, took her kids, left the donkey, and fled to the surrounding hills. I think she thought I was from some tourist group because of the way I dressed. Since my 'father' told me that one can never simultaneously have his Self and be an Other [mā fì wähad illi yākhodh zamāno wazamān gheiro-a Mzeini proverb], I wear long pants and a shirt. Yet I cover my head with a Bedouin white headdress ['amāma] because it helps against sun and dust."

"Yes, it helps," echoes Rāshda, smiling and winking.

"It helps indeed," Salīm follows with a serious voice (cf. Basso 1984). ${ }^{11}$

" 'Good morning, a morning of roses and jasmines to you, the mother of children,' I shouted to the woman while she was running away. 'God will bring good to your children,' I continued with a dry 
throat. Suddenly, the sound of rolling pebbles stopped. The woman stopped running. She was trying to listen carefully.

"I am from the people of Dahab, under protection of Khnēibish, son of 'Auda, son of Sabah, from [the agnatic blood group of] Wlad Salìm, of the [clan] Ghseināt, from [the phratry named] Wlad 'Ali,' I said in the way you taught me to introduce myself."

"Exactly in the way we taught her to introduce herself," Ghānma repeats my words to the rest, whose attention moves from my corner to her spot near the bubbling tea kettle, and then immediately back to my corner.

“ 'Are you the one people call "the one who writes us"? Her color is like yours, and your hips, like hers,' the woman shouted, removing her veil so that I could hear her more clearly [and also to connote that I was no longer a stranger].

" 'Yes it's me. I "cut" down the wadi [Mzeina's vernacular] from 'Ein al-Akhadar,' I said. She returned to her donkey, who stood calmly at the wadi's center and brushed his tail back and forth, trying to shoo the flies from his back. And I approached her. The moment her children noticed my clothes, they started crying. We greeted each other, hugging the back of each other's neck and rapidly uttering, 'Salamāt, Salamāt, Salamāt,' kissing the air three times, swaying back and forth to the rhythm of the greetings. This is exactly how you taught me to greet women."

"And this is exactly how we taught her to greet us," echoes Mabsūta, swaying her head back and forth.

" 'Shut up, kids! This is a woman from the people of Dahab, on the coast. That's the way our people there learned from strangers how to dress, so don't be afraid,' she soothed her kids while winking at me.

"Then she said quite formally, 'I am Ftaima, daughter of 'Abdallh, son of Mahmūd, from the Rawāḥla [clan]. Our people encamp in Umm Ba'atheirān, near here.'

" 'You must be the sister of Faț̣ūm, son of 'Abdallh, son of Maḥmūd. I met him with the rest of the Shadhādhna [the phratry to which the Rawāhla clan belongs] last week, during the pilgrimage to Farānje,' I said, trying to find mutual friends and relatives [nās wa'éila]."

"Friends and relatives," Abu-Mūsa mutters to himself while rolling his prayer beads between his right-hand fingers.

"Yeah, my brother told me that you even donated money for repairs to the shrine, like all the rest. Allah's blessing upon you.'

"Suddenly we established eye contact. Fțaima held my arms and 
said, 'You, what's wrong with you?! Your eyes are red and yellow! Last night-where were you?' I told Ftaima the events of that night.

" 'No one believes Shgettef. Three wives have left him. The Fool is a fool,' she said angrily. Immediately she searched the pocket sewn to the bottom of her headdress [wugā] and took out a mash of sweet and large dates. 'Eat, my child,' she said. I ate the dates as if they were manna from heaven and said, 'God will bring peace to the mother of children.' She smiled, and we started walking toward the well while gossiping about who's doing what in Dahab, and in Umm Ba atheirān and vicinity.

"Arriving back at the well, Fțaima seated me and her kids in the shade and then went to gather dried twigs. She soon returned and started kneading dough, from which she baked gurs bil-när [a type of bread served to guests]. She served it with hot, sweet tea."

"So Fțaima served her little guest gurs bil-nār soaked in tea," adds Salīm.

"We spent a whole day near the well. Goatherds arrived. A man on his camel passed by. A sheikh and his family on their personal pilgrimage to the shrine of Hbuss, there to ask for health, joined our lunch. Ftaima told my story to everyone. 'The fool can't tell who's a guest and who is an outsider,' they said."

"The Fool is a fool," some of the audience murmur to themselves.

"Just before dusk we slowly carried ourselves back to Umm Ba'atheirān. Fțaima brought me to the mag'ad. She introduced me and my Bedouin assal [descent line] to the men and told them my story. One went aside and took from a box a long and narrow rug, reserved for guests. He spread the rug and told me to sit on his right. And we found out that we had all joined in on the last pilgrimage to Farānje.

“' The duty of hospitality is with us tonight,' said Ftaima's husband, who sat down to my left, between me and the other man. He took green coffee beans from one of the boxes and roasted them in a pan on the glowing embers. Then we heard the blessed sound of a pestle beating the mortar, and echoes answered from the surrounding hills. We started to drink cycles of bitter coffee followed by sweet tea, as hosts and guests do."

"As hosts and guests always must do," Abu-Mūsa slowly and firmly repeats the end of my sentence while the rest nod their heads in agreement.

“' 'Tonight is a night of meat,' Fțaima’s husband declared solemnly. 

honor.'"

“ 'I am not so important that you need to waste your haläl in my

While I'm telling this detail to my audience, the anthropologist notes that I used the Bedouin vernacular, where halal refers to livestock. Interestingly, she muses, in classical Arabic, as well as in the Mzeina vernacular, halal is what is permitted to Muslims, as opposed to haram, the taboos. I cut short her scholarly meditations, reminding her that I'm in the middle of telling a Bedouin story to a Bedouin audience.

" 'I swear to God, I have no hunger for meat!' I said firmly, as you taught me to say in such situations."

"As we taught her," echoes Omm-Mūsa.

"So Ftaima's husband didn't press any more. After the maghreb prayer, Fțaima's eldest son brought a tray packed with rice and those precious dried fish. We blessed, ate, blessed again and washed our hands. After dinner, the men prayed the 'asha. Then, we talked about things, the situation, and the world."

"Things, situations, and the world," Salim repeats the end of my sentence. "Ya rab [oh, God], how she learned to talk like a Mzeini," he continues with astonishment.

"Then Fțaima returned, her hands loaded with blankets, and asked if I wanted to be hosted as a woman [i.e., to sleep at the corner of her family tent], or as a man [i.e., to sleep alone in the magad]. After a short argument, I convinced her that my sleeping bag was quite adequate, the same way you taught me to say things in such a situation, and I slept in the magad-as you instructed me when I asked you what I should do when I am invited to stay in a woman's tent while her husband is home."

"Right!" Omm-Mūsa approves of my action.

"Aa-ha!" agree some of the rest.

"Three evenings I spent with the men, and wrote about summer migrations, and date tree ownerships, and conflicts, and trials, and the Israeli and Egyptian governments, and the Camp David agreement, and on war and on peace. Three days I spent with the women, and wrote about marriages, and divorces, and births, and illness, and amulets, and herds, and on the Camp David agreement, and on war and on peace.

"Afterward I rented a camel and joined riders who came from 'Ein al-Akhadar, and we went down to the orchards of Tarfat al-Gdeirain. 
And here I told you about Mzeina's tradition of hospitality, and this is the end of my story, and this is your peace."

The anthropologist instructs me here to end with this common closure of stories or rhymed epics.

"And this is your peace," everyone responds in unison.

Once again Salim turns on the transistor radio and hunts for late night news.

$i i i$

During the following winter I related my 'Ein al-Akhadar story five more times to groups of Mzeinis. The context leading to it was always some unsolvable argument about the Mzeina tradition of hospitality. Among the "guests" who arrived in the Sinai that winter were highranking army officers of Egypt, Israel, the United States, and the United Nations various developers of large-scale international tourism making preliminary surveys for the Egyptian government, and thousands of tourists, who felt that this would be their last chance to catch a glimpse of the "real" wilderness of the South Sinai peninsula before it lost its pristine charm forever.

I spent that spring in Jerusalem, completing my B.A. and classifying piles of fieldnotes in preparation for graduate school in Berkeley. I puzzled over whether my story reconstructed the Mzeinis' image of themselves, or their image of me, or perhaps even of my professional image of myself. I was also unsure whether my role as an anthropologist included telling the people I studied stories about themselves.

In May 1979, I returned to the Sinai but felt embarrassed asking why Shgẹtef and Ftaima had treated me in contradictory fashions, what the meanings behind their actions were, and what meanings my story had generated.

Ramaḍan in August 1979 was the last month of my fieldwork. Arriving at Dahab, I told myself that this was my last chance to decode the mystery of contradictions. Was I just another Israeli to the Mzeina? And if so, why was I assigned a fictive genealogy and adopted into the tribe?

During the long, hot days of the daytime fast, everyone but the children napped between the daily prayers. In the shade of date trees 
on the outskirts of the settlement, men lay on the beach. The women rested in the huts. During the short nights men gathered in their mag'ad while women gathered in one of the huts, each group spending its time eating slowly, reciting long traditional poems, or discussing human relations.

12 August 1979, Dahab, 11:00

Since I didn't wake up and thus missed the late night meal, I go down to the coastline to gather some sea snails which I'll boil for lunch. I notice Abu-Mūsa and 'Id stretching after post-morning-prayer naps. In preparation for the noon prayer they go down to the tidal zone and wash their arms, legs, and faces in the sea. I finish gathering sea snails and sit nearby, under the shade of a date tree. On this dry, hot day the three of us are captivated by the moist caress of the breeze as we wait for the muezzin's cry. I am reluctant to interrupt the flow of silence, but I have only three weeks left.

As if talking to myself I hesitantly say, "Ever since last summer, I have been perplexed as to why Shgettef-the-Fool sent me, with all my equipment, to the deserted Bir al-Sarādga."

A long moment passes till "Id says, "You are an Israeli. Very soon, all sorts of Jews will go away from here, and then the Egyptians will come. Now we don't owe you anything any more. Not that we want the Egyptians over here, but your peace has left us no choice. Shgētef knows that like the rest of us."

More long moments pass, during which I count over and over again the sea snails in my lap.

"If so, why did Fțaima respect me with all the tradition of hospitality?" I ask with less hesitation.

Abu-Mūsa shifts his back, negotiating a new leaning position on the date tree trunk and says, "Because you are one of us. You are the one who writes us. Write that we have a proverb that says: ' $O$, flee from the friend who abandons you, in his hands lie your family's graves. But breastfeed him who breastfeeds you-tell your children to serve him like slaves' [min 'adāk 'adī-'omrok ma-hu fi ìdo; wamin dadāk dadī-wakhalli wlädoc 'abīdo]. Now, we breastfeed you with our lives and with the stories about our lives, and your children are the notebooks you fill. That's why you're almost twenty-five and still unmarried. And the stories in your notebooks on our lives and our words serve us too, and one day they'll also serve our children."

At this moment I suddenly perceive the paradox and say, "Once 
you taught me that one can never simultaneously have one's Self and be an Other."

Abu-Mūsa and 'Id spontaneously rhyme their answer, "But the one who writes us has taken both selves."

And then we laugh.

22 August 1979, Dahab, 17:00

The last day of the Ramaḍann fast. Ghānma's hut. Ghānma, OmmMūsa, and I have just finished cooking the meal that will break the fast. We try to keep talking in order to forget our hunger and the creeping time. I sneak in a tough question. "By the way, why did Shgētef-the-Fool fool me last summer?"

"Don't worry," says Omm-Mūsa. "Next year he'll do the same thing to every Egyptian who sniffs around 'Ein al-Akhadar. He didn't know that you're also from here."

My feeling that the politically alert "Fool" knew exactly what he was doing is strengthened. I guess that that "memorable night" was part of the price I pay for being an Israeli who studies a Muslim Arab culture. I am very sad and silent for a while, but still-

"And Fțaima, God bless her, does she think differently?" I continue. Ghānma laughs, "The women of Umm Ba'atheirān saw the tourists only a few times in their lives. For them, every one who knows how to say, 'I am a Bedouin,' is a Bedouin. Ah-the people of the highlands!" And she laughs contemptuously.

I take a deep breath and dare to ask it: "So, what do I mean to you?"

Omm-Mùsa answers decisively: "You are the one who writes us. Once we had a silly argument about what kind of Bedouin we are, and you had your notebook opened, and read us one of the stories about our roots."

"OK, but other Israelis also write about your lives," I argue.

Omm-Mūsa thinks for a moment and says, "True, but all those people do not physically stay only with us when they come to the Sinai. They live in the settlements of the Jews."

Ghānma continues and compliments me on how well I fish and graze and churn yogurt and climb on date trees and ride camels and play the goatherd-flute, and whatnot, after four years of living with the Mzeina. Why does she try to make me feel so good about myself now, when I am about to leave? She has always been so 
honest with me. I stop listening attentively and become immersed in my own thoughts. I perk up when I hear her say:

"And your eyes are as dark as ours, and you don't become a roasted lobster after long days in the desert sun." Noticing my response, she pauses.

It's my turn to talk now, but I can only search for the words. At this silent moment we once again become aware of the smell of the taboo food and of the animal coiled in our souls, ready to pounce at the moment the muezzin cries for the last time, "Eat now, you who are fasting!"

"My roots are jumbled." Thankfully, in the shade one cannot easily tell that I am blushing. It never occurred to me that my split Israeli ethnic identity would be of any interest to the Bedouinaside from the fact that the many Mzeinis who went to the Al-Aqsa mosque in Jerusalem for the Friday prayer visited the nearby house of my grandmother. She speaks a Yemenite dialect of Arabic, one very close to the Eastern Bedouin dialect, ${ }^{12}$ and she felt she had to reciprocate the hospitality her granddaughter received in the South Sinai.

"One of my halves is from Yemen. In Israel we are called Arab Jews." I immediately stop without finishing what I had intended to say. Suddenly I connect my Israeli label with Mzeina vernacular. In the South Sinai dialect of Arabic only Bedouin are referred to as Arabs. The rest are labeled peasants or city dwellers, who are Egyptians, Syrians, Lebanese, or natives of other Middle Eastern countries. For them, an Arab Jew is a Bedouin Jew.

"Aii-wah! [yeah!]" The eyes of the two women light up. "We know you, ya Smadar," says Ghānma. "Only you and Mister Marri, the English Bedouin, lived with us," continues Omm-Mūsa. And the anthropologist immediately connects Mister Marri with G. F. Murray, the only one to actually live with the Mzeina for a couple of years during the 1920s, and with his travelogue, Sons of Ishmael (1935). ${ }^{13}$ "You came here to update and correct his book... Both of you always told us how beautiful it is to climb to the top of mountains just for looking at the rest of the mountains. Besides, my great-uncle taught Mister Marri to fish, and my husband taught you to fish. Old people like me know how to connect the past with the present [illi kān

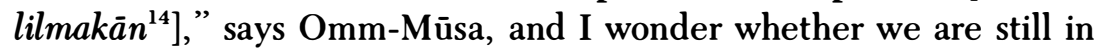
the same story or if perhaps we have started narrating another one. 
More historically, we can note that allegory seems regularly to surface in critical or polemical atmospheres, when for political or metaphysical reasons there is something that cannot be said.

-Joel Fineman

The Mzeini reality of the perpetual occupation of their land generates an atmosphere of continuous crisis. The polyphony of many Mzeini voices presented here means that one of the few avenues for protest still open to tribal members, torn between economic and cultural survival (Lavie and Young 1984; Marx 1977, 1980), is transmuting their experience into ongoing allegories rooted in tradition. ${ }^{15}$ These allegories have a dialectical nature (Benjamin 1985: 175): they sustain the Mzeina's belief in the immortality of their collective tribal past, and they demonstrate to the Mzeinis the extent to which they are entrapped in the global fluctuations of the present. ${ }^{16}$

At that moment of "emergence" (McHugh 1968: 24-8) in Ghānma's hut, I could link the tradition of hospitality to the here-and-now-inSinai of the Camp David Accord in only one way: by stylizing the month-old pain and frustration expressed in my field diary into an emotionally detached story of the present. But, my story of the present recalled to Omm-Mūsa a story of the "once upon a time" genre, the story about Mister Marri. ${ }^{17}$

Unlike other literary forms, allegories can be conceived as cultural narratives that contain within themselves a critique of that very narrative (cf. Frye 1967: 89-90; Quilligan 1979: $25-6) ;{ }^{18}$ they are thus the "tropes of tropes," "representative of critical activity per se" (Fineman 1981: 27). Therefore, allegories voice simultaneously subjective and objectified representations of the text and its many meanings. It can be noted that the same ideas were unfolded, refolded and unfolded again in my field diary, in the evening conversation at Ghānma's hut followed by my distanced story, and in conversations with Abu-Mūsa, 'Id, Ghānma, and Omm-Mūsa eight months later. My "memorable night experience" is reflected in my story, and my story reflects the 
shared experience of Mzeina and myself-an experience transcending the temporal boundaries of my fieldwork. Such stories within stories about stories evoke a hall of mirrors. Mirrors, like allegories, attempt at capturing the inclusiveness of time spans and the completeness of spaces (Wimsatt, 1970: 215-21).

During my four years of fieldwork among the Mzeina, I recorded many mundane, after-prayer conversations that degenerated into loud and painful arguments. Some of these arguments were open-ended, abruptly discontinued, and never resolved. Others ended in a communal agreement accompanied by an elevated feeling of "communitas" (Turner, 1969: 96-7).

In my third year I noted in my field diary that the latter kind of debate reminded me of a sonata form. Like the first movement of a sonata, these conversations/debates consisted of a thematic exposition, a development phase exploring and exhausting the many variations of that theme, and a grandiose finale in which the original theme is recapitulated. The Mzeina's after-prayer arguments did not match the sonata's rules of vocality, however; the exposition of the argument's theme and its many explorations was multivocal, but a solo voice recapitulated the theme. Although the voice was single, it had the persuasive power to tie together the debate's loose ends, bringing the argument to a harmonious finale.

Tracing the sources of such powerful solos, I discovered a handful of people, including myself, who had the theatrical talent to play on the fact that, though Mzeina's tradition is marginal to everyday life circumstances, it nonetheless defines the identity of each tribesperson. Common to all of us was the fact that, like that "otherness" (allos) of allegories, ${ }^{19}$ we were all capable of conjoining the Mzeini Self and the occupier's Other within ourselves. When any of us chose to rise up spontaneously and participate in the discussion, he or she changed the abrupt open-endedness of the argument by recapitulating its major theme.

I call these creative individuals "allegorical types." Gifted with the dramatic power to persuade, they summated the arguments by improvising on traditional tribal forms and poetically "adjusting" these forms to the lived experience of the present. ${ }^{20}$

I also recorded traditional stories and poems about most of these characters. One was "The Western yet Bedouinized Explorer," a category to which Mister Marri and I belong. The poems and stories made me realize that our lives as the allegorical types of the present 
extend beyond the life span of us as individuals. Hence, one might argue that allegorical types are creative personae.

When individuals acted as allegorical types they improvised upon their own life experiences and recapitulated them as stylized stories. ${ }^{21}$ In so doing, they communicated not only a message about themselves as particular types but also one about the historical context of Mzeina's general social structure and cultural action. But these creative personae were also ordinary persons. The question poses itself: what in the social context allowed these persons to move into and out of their allegorical selves?

In the midst of their ad hoc routines (Garfinkel 1967: 35-6), conversations of Mzeinis sometimes drifted from matters of daily life to the very essence of their being-in-the-world as members of a Bedouin tribe. ${ }^{22}$ Reflecting about themselves in this reductionist fashion, Mzeinis' routine typifications of reality became discrete, contradictory, anomalous, and paradoxical (Grathoff 1970: 58-61). Imbued with liminal qualities, the paradoxes characteristic of ritual transformations surfaced into both the context and text of everyday dialogues-until the participants in the situation were struck by their powerlessness in defining their own situation (McHugh 1968: 42, 52).

At that moment a creative person sometimes rose up, became a persona, and acted as an allegorical type. By entering into an inconsistent social situation with an allegorized experience, he or she reconstructed the thematic meaning of the social context. In this way the person/persona was able to eliminate open-ended discontinuity and to transmute the paradoxes of the precarious reality the Mzeina take for granted into an allegory of temporary make-believe linked to the immortality of tradition (Handelman and Kapferer 1980; Handelman 1981, 1986). ${ }^{23}$

The allegorical type transformed all the participants in a mundane situation into partakers in the non-negotiable frame of ritual/play (Handelman 1977). The ritual/play was constructed according to the unambiguous messages of the person about him- or herself as a type. Hence, the social selves (Mead 1962: 140) of others became irrelevant during the type's performance. Nevertheless, as may be seen in my example, the selves of the audience were implicitly involved in the telling and interpreting of my allegory (G. Clifford 1974: 36; Quilligan 1979: 226). In retrospect, the allegory evidenced an identity that the participants sensed in themselves before the artistic intrusion of myself-the-type into their everyday life. Therefore, during the myself- 
the-type performance, each phrase was acknowledged by "expletives signaling that the images created are not simply understood, but are enhancing the listener's appreciation of the story" (Basso 1984).

Northrop Frye has argued that allegory is interpretation, "an attaching of ideas to the structure of poetic imagery" (1967: 89-90). I would add that, in the Mzeina case, the interplay of allegorical images affected both poetics and politics-conjoining new experiences attached to the traditional structure of tribal poetics with global ideas affecting the old yet liminally unforgettable political structure of the tribe. ${ }^{24}$ Mzeina's allegories were, therefore, "successful as allegory only to the extent that [they] could suggest the authenticity with which the two coordinating poles," the poetic and political, "bespeak each other" (Fineman 1981: 83). And the reservoir of authentic types who performed these allegories of current experience, living personae who at the same time are the main characters of traditional stories, helped the Mzeina to construct their identity as an "ideal type" (Weber 1949) of a Bedouin tribe.

Whenever I related my "memorable night" story to a Mzeini audience, I became that quirky tension dissolver, that Mzeina theatrical figure who appeared on the societal stage when Mzeinis asked themselves whether their tribe exists at all, and if so, at what level of organization. Narrating my personal experience, I-the-type bridged the geopolitical paradoxes of the present and the traditional forms and figures of the past. In this way I provided a set of specific answers to certain existential and organizational dilemmas arising from the unpredictability of everyday life in the Sinai.

But the allegorical type is an objectified analytical concept. Paradoxically, ${ }^{25}$ by becoming one such concept myself, I have become my own anthropological construct. Is this yet another puzzle to solve in this double-reflexive text?

\section{IV}

Writing about the process of authorship in allegorical narration, Paul de Man has argued that "the moment when th[e] difference" between the persona of the author and the persona of the fictional narrator "is asserted is precisely the moment when the author does not return to the world. He asserts instead the ironic necessity of not becoming the dupe of his own irony and discovers that there is no way back from 
his fictional self to his actual self" (1969: 200). And interestingly, both de Man (ibid.) and Arthur Koestler (1964: 73) have viewed allegory and irony as the two poles of a similar genre.

I think it would be somewhat easier for someone who feels like an equal member of Western Culture to agree with de Man's assertion. Nonetheless, I feel that my allegorical Other (The One Who Writes Us) and my personal Self (consisting of both The Anthropologist and Smadar the woman) are fused. Searching for my identity, as the Bedouin do, I find that it is not at all an essence but entirely conjunctural, arising out of the circumstances of my being born into a certain family in Israel, and my choice of profession.

Part of my identity is that of a Western-trained professional anthropologist. Moreover, my father was a Northern European. From my mother I have my Arab culture, color, and temperament. In spite of the fact that ethnic identity is determined by the Israeli government according to the father's origin, and thus I appear as a European piece of data in bureaucratic statistics, it is my Arab half that counts socially. Since I am of dark complexion, Israelis always assume that I am a full Yemenite and treat me accordingly. Unlike my European descent, my Arab heritage qualifies me (at least in Israel) as a genuine, semicivilized Other. During my graduate studies, as I went back to classifying and analyzing my fieldnotes, I noticed that a theme of two exotic and voiceless Others emerged: my life experience in Israel was somehow mirrored in the life experience of the Mzeinis-and theirs in mine.

As a woman anthropologist, I was fully dependent on the Mzeina's hospitality once I reached the South Sinai. When the tradition of hospitality was called into question, despite my embarrassment I felt an urge to rise up and allegorize my Shgetef-the-Fool and Ftaimaand-her-two-toddlers experience. In spite of being a stranger dressed in baggy jeans and a Mickey Mouse T-shirt, I had been taught how to introduce myself to my hosts. Whenever I introduced myself to my Bedouin hosts, I momentarily became a living representation of their traditional tribal structure and organization. I was adopted by the tribe and was shown the path of Mister Marri. I was breastfed on stories about the life of the Mzeina, and now, by telling you my anthropological interpretations, I am enacting once again "the one who writes us."

Insofar as my Self is composed of two quite distinct identities, I am myself a composite of two Others. Each half of me is the Other of my 
other Self. I am able to be an Other both to European Israelis and to the Bedouin Mzeinis. In an ever more complicated relationship, I could spontaneously satisfy the Mzeinis' need to have someone play the part of an Other who, simultaneously, is not an Other. As neither identity may be reduced to the other, like those other quirky Mzeini tension dissolvers, I am in myself a metaphor of bifurcation, of unity in division, of a paradox without resolution. History and geography thus dictate the biography of an individual — and that of a tribe-in metaphor, the real poetics of politics.

\section{Notes}

1. The Arabic words in the following text are transliterated according to the Mzeina vernacular, not according to Modern Standard Arabic. Therefore, in the vernacular, the classical " $q$ " becomes a " $g$," pronounced like the "g" in "good." In transliterating Mzeina vernacular, I have oriented myself more or less on the standards of the International Journal of Middle East Studies.

2. Mag'ad rejjäl, hereafter, simply magad, is a space designated for Bedouin men and their guests. In a semipermanent settlement such as 'Ein al-Akhadar, it consists of a structure of one or two parallel stone walls, supported by wooden pillars and roofed by sheet metal. The mag'ad is at the spacious center of the settlement. In a temporary summer encampment, the mag'ad consists of a stretched sheet of woven goat hair, providing protection from sun and wind. It is located at the outskirts of the tent cluster, so that the men and their guests are set apart from the camp's hustle and bustle, and so that the privacy of the women and children is not invaded. In the middle of the mag'ad's designated space is a circle of stones marking the stove area in which there are some burning coals. In the corner are two to three storage boxes where coffee beans, tea, sugar and flour are stored, together with a pestle and a mortar, a roasting pan for the beans, a copper coffeepot, an aluminum teakettle, special cups for tea and coffee, and sometimes a round piece of sheet metal on which flat bread is baked. Long, narrow, handwoven rugs, the best of which is reserved for guests, are used for sitting or reclining in a circle around the embers.

3. In the last century the Sinai Bedouin have been governed by the Ottoman Turks, the British, the Egyptians, and the Israelis. During the last thirty-five years, the government of the South Sinai changed hands six times: from the 1940s until 1952, the Sinai was governed by the Egyptian King Farouq and patrolled by British army units. Between 1952 and 1956, it was under independent Egyptian control. In 1956, it was occupied by Israel, backed by France and Britain. Between 1956 and 1967, it was returned to the Egyptians, who were aided by the Soviets. Between 1967 and 1975, it was occupied again by Israel. Between 1975 and 1982, Israel withdrew from the Sinai in five stages in order to return it to Egypt once again.

4. I wish to thank Don Handelman for pointing out to me this crucial point.

5. I wrote my field diary in Hebrew. I also wrote my fieldnotes in Hebrew, but I recorded the voices of the Mzeinis in Arabic, using the Hebrew alphabet. Arabic and Hebrew letters are written as different graphic symbols but represent similar vowels and consonants. Since many Mzeinis owned cassette recorders and used them 
to record their friends reciting poetry or rhymed epics, or songs and favorite radio programs, I noticed that many people felt uncomfortable when I asked permission to use a cassette recorder to record their daily dialogues. They suggested I write their mundane conversation in my notebook while sitting in some corner. It was much easier for me to write Arabic in Hebrew letters as I write Hebrew more quickly.

6. The reader familiar with purdah cultures, of which the Arab World is one example, may wonder why I, as a woman, appear here and throughout this essay in male and female contexts. Because the South Sinai Bedouin have long been accustomed to the influx of tourists, developers, soldiers, and other Westerners, both male and female, it was not difficult to develop strong nonsexual friendships with Mzeini men. Both Mzeini men and women poked fun at my facility in moving between the genders, saying, "Smadar has the body (jism) and soul (nafs) of a woman and the logical mind ('agl) of a man." They explained that I could churn yogurt and play the flute, as well as gallop on camels and talk foreign currency rates. My time in the field was divided equally between the daily and ritual spheres of men and women. Both employed me as a go-between in romantic trysts. This would suggest that, despite my "trans-gender mobility," I enjoyed the trust of both. In retrospect, the only person to suffer from these circumstances was myself. After four years of genderless identity, my four years in the field, it was a real struggle to regain a distinct sense of womanhood. Interestingly, Amal Rassam [Vinogradov] also mentions that the men "graciously put up with [her] female presence in their jama'as," or official gathering places (1974: v). This despite the fact that the tribe she studied did not live in the surreal context forced upon the Mzeina, on which I elaborate in subsequent pages.

7. Many communities of the Mzeina have a male character called the "fool," or al-ahabal. This person is allowed to violate many of the tribal codes of conduct; thus, he is able to serve as a legitimate device for criticism of both tribal ideology and everyday life (cf. Lavie 1984, 1990, 1991).

8. Tanīb (sing., masc.) or țaniba (sing., fem.) is a person who does not belong to any lineage of the Mzeina, and who is given fictive kinship ties by a patrilineage of the tribe, so that he or she is protected by the Bedouin legal system.

9. The following conversation has been generously pruned. The names of the participants appearing in the following vignettes have been changed. The translation seeks a middle way between the claims of literalness and those of aesthetics.

10. This may sound rather fantastic to someone unfamiliar with some of the tourists who arrived in the Sinai during the Israeli occupation. As a matter of fact, more than a few hippie backpackers engaged in coitus in front of the shocked Bedouin, who later named it "Film Screening for Free," or Cinema Balash. The Bedouin organized one delegation after another, each of which pleaded with the peninsula's Israeli military governor to put up signs requesting the tourists to wear bathing suits. The military governor advised these pious Muslims to learn to enjoy the "show," and refused to take any further action. The Bedouin had to acquiesce, because hippie tourism was a major source of household income in Dahab and a much more attractive choice than cleaning toilets in Israeli hotels in Eilat. When a famous Ha'aretz (major Israeli newspaper) journalist became interested in the moral costs to the Mzeina of the extracurricular activities of the military governor, I was harassed for several months by the governor and his aides.

11. Such echo statements are the dialogical participation of the audience during monologic storytelling sessions. They usually appear at the end of each episode. This issue is further developed by Basso (1984), who terms the responder to a monologue a "What Sayer"; in this article she discusses that person's crucial role in the preservation of traditional knowledge in nonliterate cultures. 
12. (See also note 1.) The consonant " $q$ " is pronounced " $g$ " in many Bedouin dialects and in the Yemenite dialect of Arabic my grandmother speaks.

13. See Murray 1935.

14. Kän ya ma kän, or kan ya-makān, is one of the sentences used to mark the opening of a story. It has a built-in ambiguity, literally meaning "it had or had not happened," contextually meaning "once upon a time, there was a place."

15. Indeed, literary critics view allegory as a story of the present that reflects the stories of some mythical or occult past (see de Man 1969, 1979, 1981, Fineman 1981, Fletcher 1964, Greenblatt 1981, Quilligan 1979, Todorov 1970, and Wimsatt 1970. Allegory thus "heals the gap between the present and a disappearing past, which without interpretation, would be otherwise irretrievable and foreclosed" (Fineman 1981: 29). Dialectically, allegory is capable of dancing between these pasts and presents by "renouncing the nostalgia and the desire to coincide," so that "it establishes its language in the void of this temporal difference" (de Man 1969: 191).

16. I thank Fredrik Huxley for pointing out this dialectical nature of Mzeina allegories.

17. I do not wish to be identified with my desert predecessor. One summer I checked out Murray's book from the Hebrew University Library and read to many Mzeinis (and members of other tribes), during the pilgrimage to the tomb of Sheikh Graii, the largest event of the tribal alliance, the parts discussing the South Sinai tribal alliance. They were amused and shocked by the fairy stories their fathers had told that young British explorer. During this pilgrimage, the three chief customary judges of the Mzeina officially appointed me to correct the "funny shame our parents brought on the writers of the Sinai." I was asked daily to read aloud my personal observations of the day, although reading interviews aloud was considered an invasion of the interviewed person's privacy; many details were added during those readings.

18. Despite my deep appreciation of Quilligan's comprehensive analysis of allegory, as a scholar of nonliterate cultures I cannot agree with her assessment that "unlike epics, which can be oral, allegories are always written" (1979: 25).

19. The word allegory is composed of allos, a Greek word meaning "other," and agoreuein, "to speak in the agora," to speak openly in the assembly or market. Agoreuein connotes public, open, declarative speech (Fletcher 1964: 2). Apparently, the paradox of Self talking openly about Self s Other is built into the concept of allegory.

20. Among the Mzeina members who may act as allegorical types are the Fool (see Lavie 1984), the Madwoman (Lavie 1983), the Sheikh (Lavie 1989), the Symbolic War Coordinator and the Judge (briefly described in this paper), the Anthropologist, and several others who are discussed in greater detail in my book (Lavie 1990).

21. Interestingly, discussing the enactment of allegories, Fletcher (1964: 5) argues that "it is the mark of allegory that its dramatis personae are abstract concepts; they have no separate existence or legend, such as the characters of myth enjoy; and as a rule they are created ad hoc, to suit a particular occasion. The occasion gone, the symbolism loses its meaning."

22. In these cultural circumstances, when the Mzeina seek the deep meaning of their being-in-the-world qua members of a Bedouin tribe, I feel that they reduce the cultural text to its essence both semiotically, à la Claude Lévi-Strauss (1967: 271) and phenomenologically, à la Edmund Husserl (1962: 48). In this context, a noesis-noema relation may be viewed as some kind of intersubjective signifier-signified relation.

23. In a pioneering article, Don Handelman and Bruce Kapferer (1980) discuss the emergence of symbolic types in ritual settings. Handelman $(1981,1986)$ further develops the concepts of symbolic typification and its relation to the performance of ritual 
transformation. My analysis of allegorical typification departs from the concepts discussed in these articles.

24. Surprisingly, whenever I asked a Mzeini for the meaning of "tribe," the first explanation was something along the lines of the "fission and fusion" model developed by E. E. Evans-Pritchard (1940; cf. Lavie 1990).

25. The paradox I refer to is one of the "class of all classes which are not members of themselves," discussed by Russell and Whitehead in their mathematical theory of logical typification (1910).

\section{REFERENCES}

Basso, Ellen B. 1984. “Monological Understanding in Dialogic Discourse.” Paper presented at the Annual Meeting of the American Anthropological Association. Denver, Colo.: November 16.

Benjamin, Walter. 1985. (1963). “Allegory and Trauerspiel.” In W. Benjamin, The Origin of German Tragic Drama. Trans. J. Osborne. London: Verso. Pp. 159-235.

Berger, Peter L., and Thomas Luckman. 1967. The Social Construction of Reality: A Treatise in the Sociology of Knowledge. Garden City, N.Y.: Doubleday.

Clifford, Gay. 1974. The Transformation of Allegory. London: Routledge and Kegan Paul.

de Man, Paul. 1969. "The Rhetoric of Temporality." In C. C. Singleton, ed., Interpretation: Theory and Practice. Baltimore: John Hopkins University Press. Pp. 173-210.

- 1979. Allegories of Reading: Figural Language in Rousseau, Nitzsche, Rilke, and Proust. New Haven, Conn.: Yale University Press.

—. 1981. "Pascal's Allegory of Persuasion." In Greenblatt, ed., 1981. Pp. 1-25.

Evans-Pritchard, E. E. 1940. The Nuer. Oxford: Oxford University Press.

Fineman, Joel. 1981. "The Structure of Allegorical Desire.” In Greenblatt, ed., 1981. Pp. 26-60.

Fletcher, Angus. 1964. Allegory: The Theory of a Symbolic Mode. Ithaca: Cornell University Press.

Frye, Northrop. 1967. Anatomy of Criticism: Four Essays. New York: Atheneum.

Garfinkel, Harold. 1967. Studies in Ethnomethodology. Englewood Cliffs, N.J.: Prentice-Hall.

Grathoff, Richard. 1970. The Structure of Social Inconsistencies: A Contribution to a Unified Theory of Play, Game, and Social Action. The Hague: Martinus Nijhoff.

Greenblatt, Stephen J. ed. 1981. Allegory and Representation. Baltimore: Johns Hopkins University Press.

Handelman, Don. 1977. "Play and Ritual: Complementary Frames of Metacommunication." In A. J. Chapman and H. Foot, eds., It's a Funny Thing, Humor. Oxford: Pergamon Press. Pp. 185-92.

- 1981. "The Ritual Clown: Attributes and Affinities." Anthropos 76 (1/2): 321-70. 
1986. "Charisma, Liminality, and Symbolic-Types." In E. Cohen, M. Lissak, and U. Almagor, eds., Comparative Social Dynamics: Essays in Honor of S. N. Eisenstadt. Boulder, Colo.: Westview Press. Pp. 346-59.

Handelman, Don, and Bruce Kapferer. 1980. "Symbolic Types, Mediation, and the Transformation of Ritual Context: Sinhalese Demons and Tewa Clowns." Semiotica 30 (1/2): 41-71.

Husserl, Edmund. 1962. Ideas: General Introduction to Pure Phenomenology. Trans. W. C. Boyce Gibson (first published in English in 1931). New York: Collier Books.

Koestler, Arthur. 1964. The Act of Creation. London: Macmillan.

Lavie, Smadar. 1983. "The Madwoman: Spontaneous Theatre and Social Inconsistencies among the Mzeina Bedouin of Sinai." Paper presented at the Annual Meeting of the American Ethnological Society. Baton Rouge.

- 1984. "The Fool and the Hippies: Ritual/Play and Social Inconsistencies among the Mzeina Bedouin of the Sinai." In B. Sutton-Smith and D. KellyByrne, eds. The Masks of Play. New York: Leisure Press. Pp. 63-70.

- 1986. "The Poetics of Politics: An Allegory of Bedouin Identity." In M. J. Aronoff, ed., Political Anthropology, vol. 5: The Frailty of Authority. New Brunswick, N.J.: Transaction Books. Pp. 131-46.

- 1989. "When Leadership Becomes Allegory: Mzeina Sheikhs and the Experience of Occupation." Cultural Anthropology. 4(2): 99-135.

. 1990. The Poetics of Military Occupation: Mzeina Allegories of Bedouin Identity under Egyptian \&Israeli Rule. Berkeley and Los Angeles: University of California Press.

- 1991. "The Bedouin, the Beatniks, and the Redemptive Fool." Quarterly Review of Film \& Video, special issue, "Discourse of the Other: Postcoloniality, Positionality, and Subjectivity," edited by H. Naficy \& J. H. Gabriel, 13(13):23-43.

Lavie, Smadar, and William C. Young. 1984. "Bedouin in Limbo: Egyptian and Israeli Development Policies in the Southern Sinai." Antipode 16 (2): 33-44.

Lévi-Strauss, Claude. 1967. Structural Anthropology. Garden City, N. Y.: Anchor Books.

Marx, Emanuel. 1977. "Communal and Individual Pilgrimage: The Region of Saints' Tombs in the South Sinai." In R. P. Werbner, ed., Regional Cults. London: Academic Press. Pp. 29-51.

- 1980. "Wage Labor and Tribal Economy of the Bedouin in South Sinai." In P. C. Salzman, ed., When Nomads Settle. New York: Praeger.

McHugh, Peter. 1968. Defining the Situation: The Organization of Meaning in Social Interaction. New York: Bobbs-Merrill.

Mead, George H. 1962. Mind, Self, and Society. Chicago: University of Chicago Press.

Murray, G. W. 1935. Sons of Ishmael: A Study of the Egyptian Bedouin. London: George Routledge and Sons.

Quilligan, Maureen. 1979. The Language of Allegory: Defining the Genre. Ithaca: Cornell University Press.

Rassam (Vinogradov), Amal. 1974. "The Ait Ndhir of Morocco: A Study of the Social Transformation of a Berber Tribe." Anthropological Papers no. 55. Mu- 
seum of Anthropology, University of Michigan. Ann Arbor: University of Michigan Press.

Russell, Bertrand, and Alfred North. Whitehead. 1910. Principia Mathematica. Vol. 1. Cambridge: Cambridge University Press.

Todorov, Tzvetan. 1975. The Fantastic: A Structural Approach to a Literary Genre. Ithaca: Cornell University Press.

Turner, Victor. 1967. "Betwixt and Between: The Liminal Period in Rites de Passage.” In Victor Turner, The Forest of Symbols: Aspects of Ndembu Ritual. Ithaca: Cornell University Press.

- 1969. The Ritual Process: Structure and Anti-Structure. Chicago: Aldine. Weber, Max. 1949. The Ideal Type and Generalized Analytical Theory. In Talcott Parsons, ed., The Structure of Social Action. Glencoe, Ill.: Free Press. Pp. 601-10.

Wimsatt, James I. 1970. Allegory and Mirror: Tradition and Structure in Middle English Literature. New York: Pegasus. 